\title{
MANAGING HUMIDITY AND DRINKING WATER IN ACRYLIC CAGES FOR REARING PARASITOIDS
}

\author{
Italo de Souza Aquino \\ Universidade Federal da Paraíba -UFPB, PB. E-mail: italo.aquino@terra.com.br
}

\begin{abstract}
The moisture level and drinking water inside acrylic boxes used to breed parasitoids can be managed by placing a Petri dish with water on top of the box and humidifying the inside with a vaporizer. Through condensation, a suspended dew pool forms inside the box just below the Petri dish, providing the parasitoids with drinking water.
\end{abstract}

Keywords: biological control; beneficial insects; Catolaccus grandis.

Manejo de umidade e de água potável em gaiolas de acrílico para criar parasitóides

\section{Resumo}

O nível de umidade e a água potável dentro das caixas de acrílico usadas para criar parasitóides podem ser controlados colocando-se uma placa de Petri com água em cima da caixa e umidificando o interior com um vaporizador. Por meio da condensação, uma poça de orvalho suspensa se forma dentro da caixa logo abaixo da placa de Petri, fornecendo água potável aos parasitóides.

Palavras-chave: controle biológico; insetos benéficos; Catolaccus grandis.

Catolaccus grandis Burks (Hymenoptera: Pteromalidae) is one of the most common laboratory-bred parasitoids for biological control purposes. The standard technique is the one proposed by Cate (1987), in which maintaining high humidity levels and providing the parasitoids with enough drinking water are important factors. Usually, they are achieved in two ways: 1) by leaving a Petri dish with water inside the cage; or 2) by spraying the cage with a mister. The Petri dish solution can lead to significant drowning of parasitoids and a consequent reduction in the size of the colony, while spraying with a manual spray, although a better option, still presents a problem - spraying enough to provide drinking water makes for a messy cage and soaked parasitoids. It is then a difficult task to remove the dead parasitoids with a paper tissue without hurting the healthy ones. In our laboratory we observed that leaving a Petri dish $(100 \times 15 \mathrm{~mm})$ with water on top of the cage after spraying the inside with a mister concentrates the humidity inside the cage below the dish. The temperature difference condenses water in the upper part of the cage and, 8 hours after placing the Petri dish on top of it, a suspended pool of water forms inside the cage, from which the parasitoids can drink (Figure 1). 
Figure 1. Condensed water (petri-dish shape) on the inside an acrylic cage (A), created by the water left in a Petri dish outside the cage for $24 \mathrm{~h}$ (B). Catolaccus grandis near pool (C).

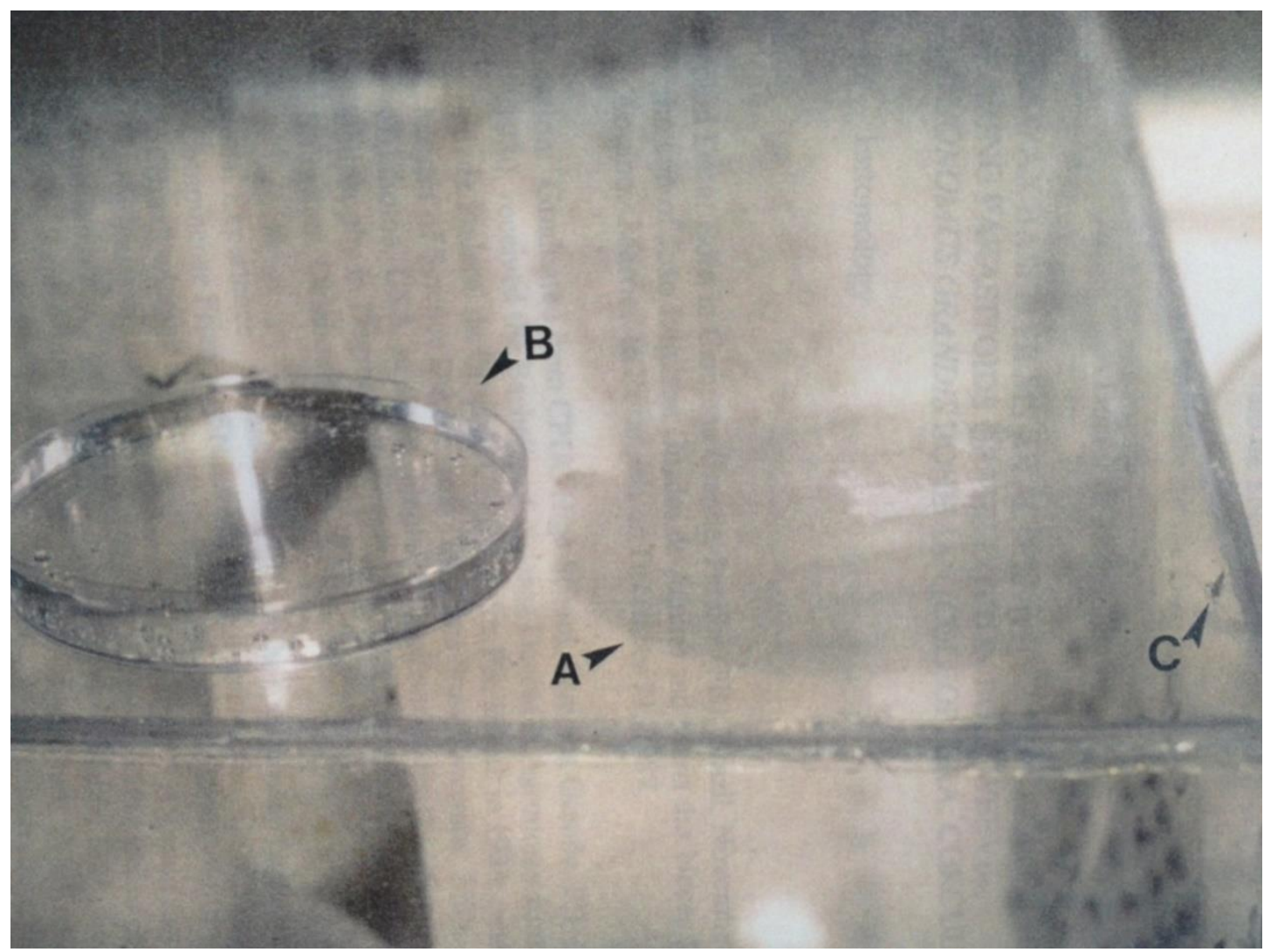

When the parasitoids drink from this "suspended pool" they do not get trapped, perhaps because they have a large dry area to land on and can approach the pool in a controlled manner. No parasitoid deaths were observed in consequence of this suspended pool and, as the water could be placed in any desired spot on top of the cage, cleaning is easier. The Petri dish must be continually placed on top of the cage so as to constantly create a suspended dew pool inside it. To better distribute the drinking water for the parasitoids, up to 4 dishes of water on the top of the cage $(45.8 \mathrm{~cm} \times 25.5 \mathrm{~cm} \times 45.8 \mathrm{~cm})$ can be used.

\section{Acknowledgments}

This study was funded in part by a fellowship from CAPES (Federal Agency of Advanced Studies) Grant No. 1.110-94-05. Special thanks to Dr. David L. Brigham (Oklahoma State University) for the review of the manuscript.

\section{References}

CATE, J. A method of rearing parasitoids of boll weevil without the host plant. Southwestern Entomology, v.12, p.211-215, 1987. 